\title{
Ecological Operation Objectives for Four Major Chinese Carps Spawning in the Xijiang River
}

\author{
Donghui Wan ${ }^{1,2},{ }^{*} \mathrm{Hehai}_{\mathrm{Xie}}{ }^{1,2}$, Fang Yang ${ }^{1,2}$, Yunyun Shi ${ }^{1,2}$, Xinghua $\mathrm{Ma}^{1}$ \\ ${ }^{1}$ The Pearl River Hydraulic Research Institute, Guangzhou 510611, Guangdong Province, China. \\ ${ }^{2}$ Key Laboratory of the Pearl River Estuarine Dynamics and Associated Process Regulation, Ministry of Water Resources, Guangzhou \\ 510611, Guangdong Province, China.
}

\begin{abstract}
The river basin cascade development has prominent influence on water ecology for breeding of four major Chinese carps, and the determination of ecological operation objectives is an important basic work to carry out the ecological operation. This study determines the main control indexes of reservoir operation by analysing the relationships between larval population of Xijiang Dongta spawning ground and impact indexes like water temperature, flood process and flow velocity. Taking peak flow, initial discharge, flow rising range, daily increasing rate of flow and duration of water level rising of the spawning ground as the control indexes, the target flow process of reservoir ecological operation can be determined. Furthermore, the drifting velocity of fish eggs is used as the test index to control the section flow in the scheduling river reach. The proposed method is applied to the ecological operation of Dongta spawning ground, and the target flow processes of ecological operation under low, medium and high flow levels are obtained.
\end{abstract}

\section{Introduction}

For the development and utilization of water resources, a large number of reservoir dams are built in China. These projects played an important role on flood control, power generation, water supply, irrigation and navigation, and effectively promoted the economic and social development, but also caused remarkable influences on watershed hydrological regime and river ecosystem [1]. The construction and operation of reservoir dams interrupted river longitudinal connectivity, cut off the migration route of fish, changed the natural hydrological rhythm and destroyed the aquatic environment, leading to a series of different degree ecological environment problems such as water eutrophication, reduction of fish spawning scale and descending of biology variety. Change in natural hydrological conditions caused by development and utilization of water resources like damming and water diversion is considered to be one of the main causes of river ecological problems [2]. Take Xijiang River basin as an example, the reservoir area formed by hydropower cascade development flooded part of the spawning grounds, and the space for fish to reproduce and survive is compressed. The original 29 spawning grounds now 17 exist only, and the quantity of four major Chinese carps decreased sharply and the fish individual is becoming smaller.

In order to reduce or compensate the negative effects on the ecosystem caused by reservoirs, people put forward the concept of "ecological operation". To maintain or restore the robust aquatic habitat, so as to achieve the aim of protecting aquatic ecosystems, hydrological processes for aquatic creatures needs can be obtained by improving the reservoir operation mode and establishing reasonable operation rules [3]. At present, the reservoir ecological operation has become an important measure of river ecological restoration, and scheduling practices has been carried out on some major rivers such as the Yangtze River $[4,5,6]$. In this paper, the main control indexes for spawning of four major Chinese carps, such as water temperature, flood processes and flow velocity, are identified by analyzing historical data of the larval population, and then the feasible ecological flow processes are obtained through research and analysis.

\section{Ecological-hydrological indexes for breeding season of four major Chinese carps}

Four major Chinese carps (Mylopharyngodon piceus, Ctenopharyngodon idellus, Hypophthalmichthys molitrix and Aristichthys mobilis), belong to the typical fishes with pelagic eggs, of which mature parent fish will gather in specific areas to spawn when there is a appropriate water level rising process during May to July of each year and the eggs will float down the river and hatching. Xijiang Dongta spawning ground (Fig. 1), located at the confluence of Qianjiang, Yujiang and Xunjiang, with significant habitat characteristics and high diversity, is the largest existing fish spawning ground of four major Chinese carps in China. A large number of previous research results indicate that the following conditions need to be met for Chinese carps to spawn [7]: appropriate water

\footnotetext{
* Corresponding author. Tel.: +86-20-87117932; fax: +86-20-38491316. E-mail address: xiehehai@gmail.com
} 
temperature, appropriate water level rising process, specific spawning grounds, and so on.

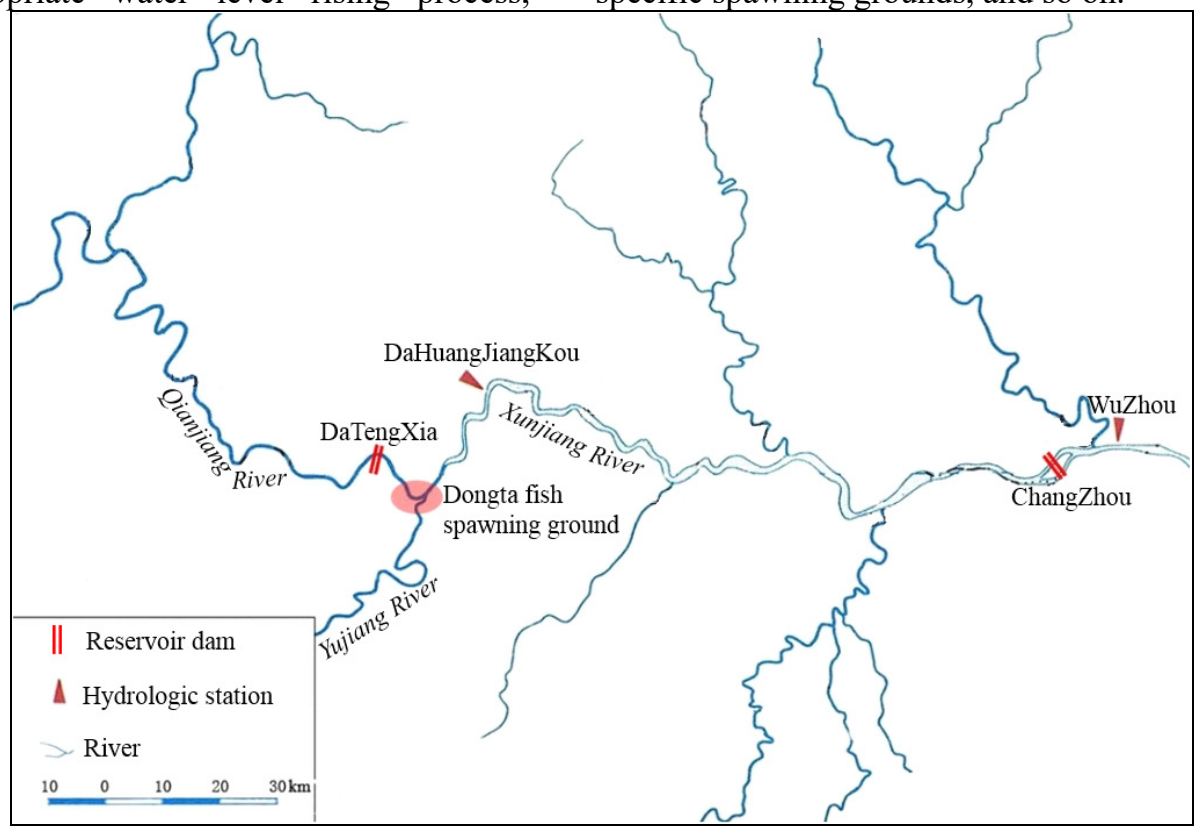

Figure 1. Location of the Dongta fish spawning ground

\subsection{Appropriate water temperature}

Water temperature is one of the most important external conditions for the growth of fish and eggs hatching. Generally the reproductive water temperature of four major Chinese carps is considered no less than $18{ }^{\circ} \mathrm{C}$, otherwise there is basically no egg laying. The related studies show that the water temperature during breeding season of Chinese carps on the Yichang reach of the mainstream of the Yangtze River is $21-23{ }^{\circ} \mathrm{C}$, and spawning activities are most frequent in this temperature range.

Using the data of fish larval population collected in the surveys from 2007 to 2013, relational scatter diagram of larval population and water temperature for four major Chinese carps of Dongta spawning ground is plotted (Fig. 2). Through statistical analysis of the maximum and minimum temperature values of the spawning activities of four major Chinese carps in Dongta spawning ground, we can come to conclusion that the water temperature range of Dongta spawning ground during breeding season of four major Chinese carps is $20.7-30.1{ }^{\circ} \mathrm{C}$, and the water temperature range when spawning occurs frequently and on a large scale is generally $24.5-28.3{ }^{\circ} \mathrm{C}$, of which the water temperature of spawning peak is $26.7{ }^{\circ} \mathrm{C}$ and four major Chinese carps spawning rarely or on a tiny scale when water temperature is less than $22.6{ }^{\circ} \mathrm{C}$.

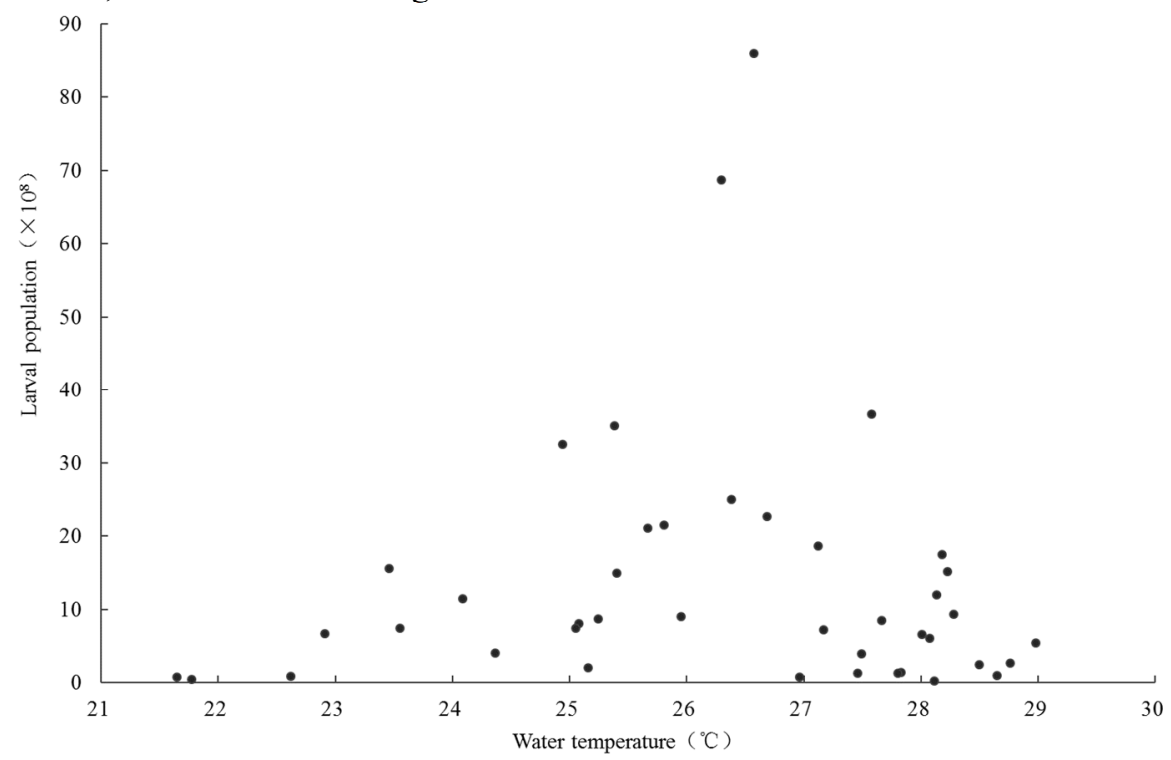

Figure 2. Relationship between larval population and water temperature

\subsection{Appropriate flood process}

Water level rising means the increase of the flow, as well as the increase of flow velocity. Most spawning of four major Chinese carps takes place during rising period of one flood, and begins after rising for some time. And meanwhile, a certain flow velocity can keep the pelagic eggs from sinking, and ensure that the eggs will be 
fertilized and incubated normally.

Based on 42 actual flood processes of Dongta spawning ground, scatter plots are plotted for the spawning activities of four major Chinese carps to characterize the relationships between larval population and impact indexes, which include characteristic flows (initial discharge of one flood, peak flow), flow rising range and average daily increasing rate of flow. Statistical analysis results support the following findings: 1) The flood magnitude is relatively broad for four major Chinese carps of Xijiang River in breeding season. The larval population can be monitored when the peak flow varies from 4780 to $35600 \mathrm{~m}^{3} / \mathrm{s}$, and spawning activities are more frequent and larval population is larger when the peak flow is $9600 \sim 17000 \mathrm{~m}^{3} / \mathrm{s}$; 2) Spawning activities are more frequent and larval population is larger when the initial discharge of the flood is $4000 \sim 6000 \mathrm{~m}^{3} / \mathrm{s}$ while flow rising range is $7000 \sim 13000 \mathrm{~m}^{3} / \mathrm{s}$; 3) Spawning occurs frequently and larval population is larger when the average increasing rate of flow is $700 \sim 3000\left(\mathrm{~m}^{3} / \mathrm{s}\right) / \mathrm{d}$, spawning activities are relatively concentrated, but larval population is relatively small when the increasing rate is $600 \sim 1000\left(\mathrm{~m}^{3} / \mathrm{s}\right) / \mathrm{d}$, and spawning of four major Chinese carps occurs infrequently and the monitored number of eggs is very small and negligible when the increasing rate is less than 500 $\left(\mathrm{m}^{3} / \mathrm{s}\right) / \mathrm{d}$.

The total average duration of the flood of Dongta spawning ground in breeding season of four major Chinese carps is 15.6 days, and the average duration of flood rising is 6.1 days, and the average rising durations of single-peak, double-peak and multi-peak floods are 4.6 days, 7.1 days and 11.5 days respectively (Tab. 1). The probability of large scale spawning of four major Chinese carps is high when the duration of water level rising is between 3 and 9 days, and the spawning activities collected in the surveys are the most frequent and the number of larval population is the largest when duration of water level rising is 5 days. The collected spawning scale of four major Chinese carps is relatively larger when the total flood duration is between 12 and 18 days.
Table 1. Characteristics of flood duration for four major Chinese carps spawning

\begin{tabular}{ccccc}
\hline $\begin{array}{c}\text { Flood } \\
\text { Type }\end{array}$ & $\begin{array}{c}\text { Total } \\
\text { Duratio } \\
\text { n (d) }\end{array}$ & $\begin{array}{c}\text { Average } \\
\text { Total } \\
\text { Duratio } \\
\text { n (d) }\end{array}$ & $\begin{array}{c}\text { Average } \\
\text { Rising } \\
\text { Duratio } \\
\text { n (d) }\end{array}$ & $\begin{array}{c}\text { Average } \\
\text { Retreatin } \\
\text { g } \\
\text { Dutation } \\
\text { (d) }\end{array}$ \\
\hline $\begin{array}{c}\text { Single- } \\
\text { peak }\end{array}$ & $7 \sim 18$ & 11.8 & 4.6 & 7.3 \\
$\begin{array}{c}\text { Double } \\
\text {-peak }\end{array}$ & $8 \sim 29$ & 19.2 & 7.1 & 12.1 \\
$\begin{array}{c}\text { Multi- } \\
\text { peak }\end{array}$ & $20 \sim 34$ & 25.8 & 11.5 & 14.3 \\
Total & $7 \sim 37$ & 15.6 & 6.1 & 9.5 \\
\hline
\end{tabular}

\subsection{Appropriate flow velocity}

At present, many studies are unable to give a unified range of spawning velocity of four major Chinese carps. Yi Bolu [8] suggested that the average flow velocity range of four major Chinese carps in breeding season on the mainstream of Yangtze River is $0.95 \sim 1.3 \mathrm{~m} / \mathrm{s}$. Yi Yujun et al. [9] suggested that the preference flow velocity range of four major Chinese carps in breeding season is $0.2 \sim 0.9 \mathrm{~m} / \mathrm{s}$. $Y i$ Bai Haixia al. [10] synthesized previous research and suggested that the flow velocity range of four major Chinese carps is large, and is generally $0.33 \sim 1.5 \mathrm{~m} / \mathrm{s}$. Liu Jiankang [11] proposed that the minimum flow velocity needed for fish spawning on the mainstream of Yangtze River is $1 \sim 1.5 \mathrm{~m} / \mathrm{s}$.

Statistical analysis showed that the initial flow velocity of four major Chinese carps of Dongta spawning ground in breeding season is generally $0.91 \sim 1.58 \mathrm{~m} / \mathrm{s}$ with an average of $1.28 \mathrm{~m} / \mathrm{s}$, and the velocity increment is $0.15 \sim 1.11 \mathrm{~m} / \mathrm{s}$ with an average increase of $0.54 \mathrm{~m} / \mathrm{s}$. Four major Chinese carps spawning rarely and the larval population is very small when the velocity increment is less than $0.2 \mathrm{~m} / \mathrm{s}$, and spawning activity is more frequent and the larval population is larger with the velocity increment of $0.2 \sim 1.1 \mathrm{~m} / \mathrm{s}$, especially when the velocity increment is $0.4 \sim 1.1 \mathrm{~m} / \mathrm{s}$ (Fig. 3).

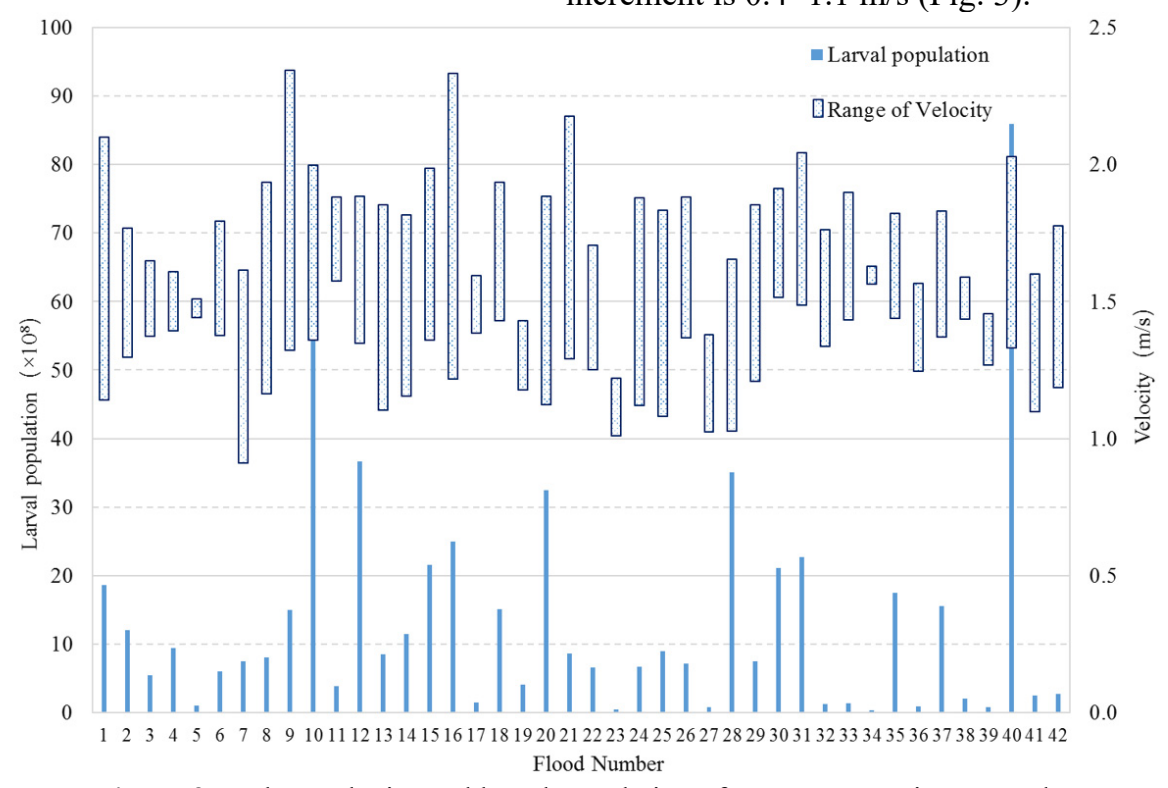

Figure 3. Flow velocity and larval population of Dongta spawning ground 
Since the relationship between mean flow velocity and flow quantity of Dongta spawning ground is relatively simple and the change of flow velocity in the spawning ground is consistent with the trend and amplitude of flow variation, the analytical minimum value and appropriate scope of flow velocity and flow indicators can be considered as same as the demand of rising process for four major Chinese carps.

\section{Reservoir ecological operation objectives in breeding season of four major Chinese carps}

\subsection{Control indexes for reservoir ecological operation}

Control indexes for ecological operation refer to the ecological-hydrological indexes to meet the ecological needs of fish as much as possible by reservoir operation. In this paper, drifting speed of fish eggs $\left(v_{l}\right)$, peak flow of the spawning ground $\left(Q_{p}\right)$, initial discharge $\left(Q_{0}\right)$, flow rising range $(\Delta Q)$, average daily increasing rate of flow $(\Delta Q / \Delta t)$ and duration of water level rising $(T R)$ are determined to be the 6 control indexes for reservoir ecological operation, of which 5 indexes of the spawning ground $\left(Q_{p}, Q_{0}, \Delta Q, \Delta Q / \Delta t, T R\right)$ are directly used to determine the target flow process of reservoir ecological operation, and $v_{l}$ is used to test the flow process of each control section in the dispatching river reach (Tab. 2).

Because fish only spawning when water temperature $(T)$ of the spawning ground is above a certain value, and water temperature of the spawning ground can hardly change from reservoir operation, so $T$ should not be regarded as an index of ecological operation and should be a key constraint factor in timing of ecological operation.

Table 2. Indexes and the control ranges for ecological operation

\begin{tabular}{|c|c|c|}
\hline Control Indexes & $\begin{array}{l}\text { Limit } \\
\text { Value }\end{array}$ & $\begin{array}{l}\text { Recommended } \\
\text { Value }\end{array}$ \\
\hline Peak flow $Q_{p}\left(\mathrm{~m}^{3} / \mathrm{s}\right)$ & $>6000$ & $9600 \sim 17000$ \\
\hline Initial discharge $Q_{0}\left(\mathrm{~m}^{3} / \mathrm{s}\right)$ & $>3000$ & $4000 \sim 6000$ \\
\hline $\begin{array}{c}\text { Flow rising range } \Delta Q \\
\left(\mathrm{~m}^{3} / \mathrm{s}\right)\end{array}$ & $>2500$ & $7000 \sim 13000$ \\
\hline $\begin{array}{l}\text { Average daily increasing } \\
\text { rate of flow } \Delta Q / \Delta t\left(\mathrm{~m}^{3} / \mathrm{s}\right)\end{array}$ & $>600$ & $1000 \sim 3000$ \\
\hline $\begin{array}{c}\text { Duration of water level } \\
\text { rising } T R\left(\mathrm{~m}^{3} / \mathrm{s}\right)\end{array}$ & - & $3 \sim 9$ \\
\hline
\end{tabular}

\subsection{Target flow process of the spawning ground}

The flow process is mainly determined by five parameters: peak flow, initial discharge, retreating flow, duration of water level rising, total duration of flood (or retreating duration). The middle process of rising and retreating can be revised according to natural flood pattern refer to average increasing rate. The basic idea of determining the target flow process of Xijiang ecological operation is as follows: First, determine $Q_{p}$ and make it in the recommended range of ecological operation control index.
Next, preliminarily identify the value range of $Q_{0}$ according to the recommended ranges of $\Delta Q$ and $Q_{0}$. Then, estimate an approximate range of $T R$ based on the recommended range of $\Delta Q / \Delta$. After that, determine a reasonable value of $T R$ on the basis of the time interval between water-rising start to spawning of four major Chinese carps and the recommended range of $T R$. So far, the characteristic parameters of the flow process, such as peak flow, initial discharge and duration of water level rising, can all be determined. Finally, the flow process of the flood is obtained.

The target flow process of reservoir ecological operation of Dongta spawning ground can be determined respectively by low $\left(6000 \sim 8000 \mathrm{~m}^{3} / \mathrm{s}\right)$, medium $\left(8000 \sim 12000 \mathrm{~m}^{3} / \mathrm{s}\right)$ and high $\left(12000 \sim 17000 \mathrm{~m}^{3} / \mathrm{s}\right)$ flow levels. Take the low level flow as an example to specify its determination method: The peak flow should be $6000<Q_{p}$ $<8000 \mathrm{~m}^{3} / \mathrm{s}$ according to the recommended range of control index in the scenario of low flow level, and the minimum value of $Q_{0}$ is $3000 \mathrm{~m}^{3} / \mathrm{s}$. The maximum value of $Q_{0}$ is $3500 \sim 5500 \mathrm{~m}^{3} / \mathrm{s}$ subjects to the minimum requirement of $\Delta Q: 2500 \mathrm{~m}^{3} / \mathrm{s}$. At this point, the average cross section velocity of Dongta spawning ground corresponding to $Q_{0}$ is $0.96 \sim 1.3 \mathrm{~m} / \mathrm{s}$, then four major Chinese carps begin to lay eggs about 2 days after initiate rising of the flood. If the concentrated spawning time of four major Chinese carps lasts for 2 days, the duration of water level rising should be no less than 4 days. And if duration of water level rising is more than 5 days, the average daily increasing rate of flow will be out of the recommended range and even less than the recommended lower limit. Therefore, it is most suitable for the duration of water level rising to be set as 4 days. The retreating duration can be roughly taken as 5 days according to the requirement of the time it takes for the eggs to develop into larvaes capable of active swimming, then the total duration of the flood should be 9 days. The retreating flow should be about $3000 \sim 4500 \mathrm{~m}^{3} / \mathrm{s}$ as the retreating rate is slightly less than the rising rate.

The above method is also applicable to determine the target flow process of Dongta spawning ground with medium and high flow level. The control indexes of the target flow process for ecological regulation are listed in Tab. 3, and the corresponding initial discharge range is illustrated with Fig. 4.

Table 3. Control indexes of target flow process of Dongta spawning ground

\begin{tabular}{ccccccc}
\hline & \multicolumn{4}{c}{$\begin{array}{c}\text { Control values of flow process at high, medium } \\
\text { and low flow level }\left(\mathbf{m}^{\mathbf{3}} / \mathbf{s}\right)\end{array}$} \\
\cline { 2 - 7 } $\begin{array}{c}\text { Sche } \\
\text { dulin } \\
\text { g Day }\end{array}$ & $\begin{array}{c}\text { Low flow } \\
\text { level }\end{array}$ & \multicolumn{2}{c}{$\begin{array}{c}\text { Medium flow } \\
\text { level }\end{array}$} & \multicolumn{2}{c}{$\begin{array}{c}\text { High flow } \\
\text { level }\end{array}$} \\
\cline { 2 - 7 } & $\begin{array}{c}\text { Lowe } \\
\text { r line }\end{array}$ & $\begin{array}{c}\text { Uppe } \\
\text { r line }\end{array}$ & $\begin{array}{c}\text { Lowe } \\
\text { r line }\end{array}$ & $\begin{array}{c}\text { Uppe } \\
\text { r line }\end{array}$ & $\begin{array}{c}\text { Lowe } \\
\text { r line }\end{array}$ & $\begin{array}{c}\text { Uppe } \\
\text { r line }\end{array}$ \\
\hline 0 & 3000 & 5500 & 4000 & 6000 & 4000 & 6000 \\
4 & 6000 & 8000 & 8000 & 1200 & 1200 & 1700 \\
9 & 3000 & 4500 & 3500 & 5000 & 0 & 0 \\
\hline Flow control during rising period: total flow rising range & \\
$\Delta Q>2500\left(\mathrm{~m}^{3} / \mathrm{s}\right), \Delta Q / \Delta t>600\left(\mathrm{~m}^{3} / \mathrm{s} / \mathrm{d}\right)$ & \\
\hline
\end{tabular}




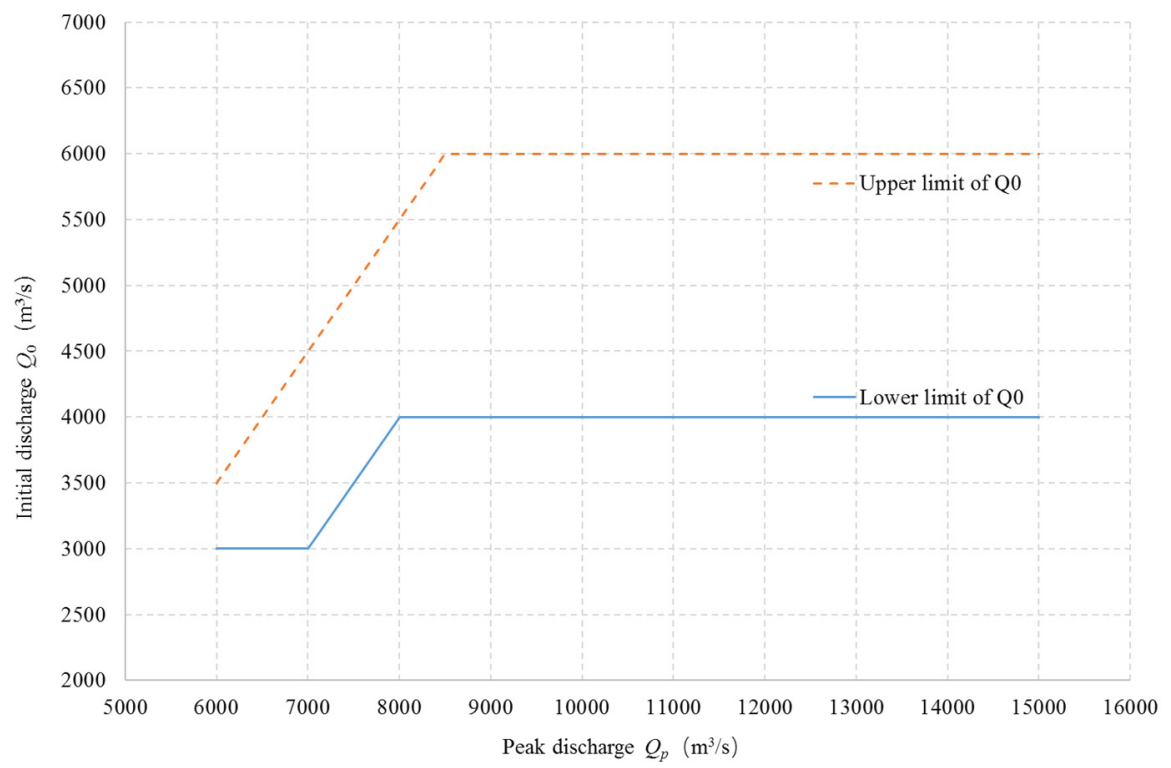

Figure 4. Initial discharge range of Dongta spawning ground for ecological operation

\section{Conclusions}

In this paper, the control indexes of the target flow process of reservoir ecological operation are identified by summarizing the previous studies and analyzing the relationships between the spawning of four major Chinese carps and the main ecological-hydrological indexes in Xijiang Dongta spawning ground. The study results indicate that peak flow, initial discharge, flow rising range, daily increasing rate of flow and duration of water level rising of the spawning ground should be as the control indexes, and the range of each index is given. The drifting velocity of fish eggs is used as the test index to control the section flow of the scheduling river reach. The target flow processes of ecological operation under low, medium and high flow levels are obtained by statistical analysis.

There are many indexes impact the spawning of four major Chinese carps and the internal mechanism is complex, and their quantitative identification is difficult. Furthermore, it is more difficult to summarize the control indexes of reservoir operation, not to mention how difficult it will be to develop ecological operation scientifically. Therefore, further research is needed for ecological reservoir operation.

\section{Acknowledgments}

This research was supported by the National Key R\&D Program of China (2017YFC0405900), Science and technology special funds project for department of water resources of Guizhou province (KT201606), Science and technology special funds project for department of science and technology of Guizhou province, Qian $\mathrm{Ke} \mathrm{He}$ supporting [2016]2561.

\section{References}

1. Guo WX, Xia ZQ, Wang YK, et al. Ecological operation goals for Three Gorges Reservoir [J].
Advances in Water Science, 2009, 20(4): 554559(in Chinese).

2. Wang JN, Dong ZR, Liao WG, et al. An environmental flow assessment method based on the relation-ships between flow and ecological response: A case study of the Three Gorges Reservoir and its downstream reach $[\mathrm{J}]$. Scientia Sinica : Technological, 2013, 6: 715-726(in Chinese).

3. Cui GT, Zuo QT. Research status and prospect of ecological regulation [J]. South-to-North Water Diversion and Water Science \& Technology, 2011, 9(6): 90-97(in Chinese).

4. China Institute of Water Resources and Hydropower Research, Yangtze River Fisheries Research Institute of Chinese Academy of Fishery Sciences. Technical scheme and demonstration effect evaluation of the joint operation of Three Gorges-Gezhouba to compensate aquatic breeding conditions of the downstream river [R]. Beijing, 2011(in Chinese).

5. Zhao Y, Zhou JZ, Xu K, et al. Ecological operation of Three Gorges Reservoir for protection of four major Chinese carps spawning [J]. Journal of Sichuan University (Engineering Science Edition), 2012, 44(4): 45-50(in Chinese).

6. Wang Y, Dai HC, Wang BW, et al. Study of the eco-scheduling for optimization Chinese sturgeon spawning habitats $[\mathrm{J}]$. Journal of Hydraulic Engineering, 2013, 44(3): 319-326(in Chinese).

7. Chen YB, Liao WG, Peng QD, et al. A summary of hydrology and hydrodynamics conditions of four Chinese carps spawning [J]. Journal of Hydroecology, 2009, 2(2): 130-133(in Chinese). 
8. Yi BL, Yu ZT, Liang ZS. Gezhou Dam and four major Chinese carps in Yangtze River [M]. Wuhan: Hubei Province Science and Technology Press, 1988(in Chinese).

9. Yi YJ. Impacts of changing flow and sediment on fish and habitat modeling of the Yangtze River [D]. Beijing: Tsinghua University, 2008 (in Chinese).

10. Bai HX, Peng QD, Li C, et al. A summary of topographical characteristics of the four major Chinese carps' spawning grounds and hydrodynamic conditions for natural propagation in the Yangtze River [J]. Journal of China Institute of Water Resources and Hydropower Research, 2014, 03: 249-257(in Chinese).

11. Liu JK, He BW. Chinese freshwater fish culture [M]. Beijing: Science and Technology Press, 1992(in Chinese). 